LIAS WORKING PAPER 1

\title{
Alternative Rites of Passage in FGM/C Abandonment Campaigns in Africa: A research opportunity
}

Authors: Laurence Droy, Lotte Hughes, Mark Lamont, Peter Nguura, Damaris Parsitau, Grace Wamue Ngare

\begin{abstract}
Alternative Rites of Passage (ARP) are a relatively recent invention, and a key element in female genital mutilation/cutting (FGM/C) abandonment strategies organised by NGOs in some regions of Africa, particularly East Africa. They aim to replicate traditional initiation rituals for pubescent girls who are transitioning to womanhood, but without FGM/C. This paper briefly describes the genesis of ARP in Kenya since 1996, and discusses its significance as a hybridised cultural assemblage that forms part of new cultural and relational processes. It emphasises the importance of examining the deep context in which ARP takes place, including the traditional ritual that it aims to replace. The paper identifies lacunae in the literature, and potential lines of enquiry for future research. The Appendix comprises summaries of a selection of the literature on ARP.
\end{abstract}

Keywords: Alternative Rites of Passage (ARP); female genital mutilation/cutting (FGM/C); Africa; Kenya; culture; kinship; initiation; human rights; development; NGOs

\section{Introduction}

This is the first in a series of Working Papers published by the Institute of Advanced Studies (IAS) at the University of Leicester. It arises from a workshop held at the IAS on 9 March 2018, on Alternative Rites of Passage (ARP) in Africa. The workshop brought together scholars, students, NGO representatives and health practitioners from the UK and Kenya, to discuss plans for a research group that will, funds permitting, undertake collaborative interdisciplinary research on ARP.

ARP (explained below) is a highly under-researched subject, compared to the closely related subject of female genital mutilation, also known as female genital cutting (FGM/C). Also, the small body of existing literature on ARP, particularly produced by or for NGOs, donors and

\footnotetext{
1 There is disagreement among scholars, practitioners and others about these terms. Some claim the word 'mutilation' is derogatory, and prefer FGC on the grounds that 'cutting' is less judgmental. FGM/C is a compromise. FGM/C is colloquially known as 'the cut' or female circumcision in Kenya and other parts of Africa.
} 
development agencies, tends to depict ARP as a (relatively) successful component of FGM/C eradication campaigns in Africa. The more scholarly research evidence challenges this assumption, and raises a large number of questions. We posit that there is an urgent need to learn more about ARP, not only to establish if it 'works' or not (which is more of a 'development' priority than a scholarly one), but also to generate solid evidence-based data, fill lacunae in the literature, and expand our knowledge of this high-profile - yet little understood or explained - social intervention. What distinguishes this proposed research from other studies is that, while testing some of the claims made for ARP, we aim to explore the deep context of ARP (and 'alternatives' more broadly) and do not seek either to validate or condemn it. Rather, we see it as a hybridised cultural assemblage that forms part of new cultural and relational processes. We hope that the proposed research findings will be of interest and value to scholars and practitioners, and others including human rights defenders, NGOs, donors, governments and civil society.

This paper is not primarily about FGM/C, but ARP. Space constraints preclude a comprehensive discussion of the issues and wider context; we hope these can be explored in future papers. It will focus largely on Kenya, referring to other parts of Africa where relevant. It starts with basic definitions, before describing aspects of ARP's role in FGM/C abandonment efforts, highlighting some important links between initiation, bridewealth and kinship, and providing (in a link) a review of the existing literature. It ends by identifying topics that may be explored in future research.

\subsection{Definitions}

Alternative Rites of Passage (hereafter ARP) are touted by the NGOs that organise them, and by other stakeholders including development agencies and donors, as a viable alternative to girls' initiation but without FGM/C. They form a central part of contemporary efforts aimed at FGM/C abandonment in Africa, in communities where girls traditionally undergo FGM/C in puberty, and where community ceremonies traditionally marked the rite of passage from child to adult, before FGM/C was outlawed. ${ }^{2}$ ARP aims not only to divert girls from FGM/C but also early marriage, which invariably follows FGM/C and forces girls to drop out of school. ARP is not practised, so far as we know, in communities where FGM/C is performed on younger girls, or on women. In Kenya, there have been several recent cases of young married women 'choosing' to undergo FGM/C, reportedly because they could not face the discrimination and marginalisation they have suffered as a result of not being 'cut', and cases of women forced to

\footnotetext{
${ }^{2}$ There are also contemporary examples of ARP being developed for boys, e.g. by Pentecostal churches in Kenya.
} 


\section{LIAS WORKING PAPER 1}

undergo it in childbirth (for The Gambia and Senegal, see Hernlund and Shell-Duncan, 2007). In such cases, and in communities where FGC/C is performed on infants, ARP cannot easily provide an alternative since no rite of passage is involved.

According to the World Health Organization (WHO), FGM/C 'comprises all procedures that involve partial or total removal of the external female genitalia, or other injury to the female genital organs for non-medical reasons' (WHO, 2018). ${ }^{3}$ There are four main types, known as Types 1 to $4 .{ }^{4} \mathrm{FGM} / \mathrm{C}$ has been outlawed in Kenya since 2001, but still persists in many communities. ${ }^{5}$ The national prevalence has steadily fallen from 32 per cent in 2003, to 27 per cent in 2008/09, and 21 per cent in 2014. The practice declines with increasing wealth and education, is more common among rural women, and less common among young women. ${ }^{6}$ There is evidence of increasing medicalisation, with medical practitioners illegally performing FGM/C in clinics, hospitals and people's homes. ${ }^{7}$

\subsection{The wider significance of initiation}

The physical act of cutting is (or was, before it was banned) often part of a larger process of initiation into adulthood that also involves - particularly in so-called age-organised communities such as Maasai and Samburu, whose males ascend through life via age-grades and age-sets - the graduation of girls, their parents and other family members to a higher stratum of collective social being. (As mentioned, this does not apply everywhere; in some societies girls undergo FGM/C in infancy, it is not a rite of passage.) The importance of this wider aspect, and the significance of the collective transformative elements of traditional initiation ritual, or new forms of ritual since public ceremonies ceased, is rarely if ever acknowledged in anti-FGM/C campaigns that centre only on stopping 'the cut'. We believe more attention should be paid to these wider aspects, in approaches to the design and roll-out of ARP as part of broader FGM/C abandonment initiatives.

\subsection{The genesis of ARP in Kenya}

\footnotetext{
${ }^{3}$ WHO, 2018. Available at: http://www.who.int/mediacentre/factsheets/fs241/en/ (accessed 2 April 2018) ${ }^{4}$ Type 1 (clitoridectomy) involves partial or total removal of the clitoris and/or prepuce; Type 2 (excision) partial or total removal of the clitoris and labia minora, with or without excision of the labia majora; Type 3 (infibulation) the narrowing of the vaginal opening and creation of a covering seal; Type 4 (unclassified) all other harmful procedures to the female genitalia for non-medical purposes, e.g. pricking, piercing, incising, scraping, cauterizing (WHO, 2018).

${ }^{5}$ FGM/C was outlawed in Kenya by the Children Act 2001 and the Prohibition of Female Genital Mutilation Act 2011.

${ }^{6}$ Kenya Demographic and Health Survey (KDHS), Kenya National Bureau of Statistics, Nairobi (December 2015).

${ }^{7}$ Medicalisation is currently in the news because of a lawsuit brought by a Kenyan woman doctor who is seeking to overturn anti-FGM laws and allow 'adult willing women' to practise FGM/C. Dr Tatu Kamau v the Attorney General and the Anti-Female Genital Mutilation Board (2017).
} 


\section{LIAS WORKING PAPER 1}

ARP, known colloquially as a 'ritual without cutting' or 'circumcision by words', was developed by NGOs as part of strategies aimed at eradicating FGM/C. Sometimes, much more rarely, alternatives to FGM/C have been developed by other players such as communities, faith leaders and churches acting without external intervention (see for example M'Raiji, 2015). Apparently first invented in Kenya in 1996, ARP has proliferated in recent years in different ethnic communities, and has become very popular with NGOs and donors. ${ }^{8}$ The leading Kenyan women's development organisation, Maendeleo ya Wanawake (MYWO), organised the first ARPs in Kenya in collaboration with PATH (Program for Alternative Technology in Health) in the Tharaka area of Meru in 1996 (e.g. Muteshi and Sass, 2005; Chege, Askew and Liku, 2001; World Bank/UNFPA, 2004). Forms of ARP have also been developed elsewhere in Africa; for example, by the REACH project in Uganda (e.g. Namulondo, 2009; 28toomany, 2013), and by the Foundation for Research on Women's Health, Productivity, and the Environment (BAFROW) in The Gambia (Muteshi and Sass, 2005). Public declarations, a component of many ARP graduation ceremonies, are central to the NGO Tostan's work in Senegal and five other African countries, though Tostan does not organise ARP as such (for Senegal see O’Neill, 2012; Mitchell and Eke, n.d.).

\subsection{Components of ARP}

There is no single model of ARP. It takes various forms in different ethnic communities, with NGOs producing their own designs and curricula, allegedly in collaboration with communities. ARP aims to mimic key aspects of traditional rites of passage, such as the seclusion of girls, their instruction by older women, feasting, elders' blessings and the exchange of gifts. Ideally part of longer-term education strategies at community level, ARP usually includes these components:

- Community sensitization and awareness-raising

- Seclusion of girls, for instruction in life skills, human rights, FGM/C, health and other topics

- A public graduation ceremony where 'initiates', parents, elders and other community leaders declare their abandonment of FGM/C, and the graduates receive certificates

Some NGOs include boys in the instruction and final ceremonies. Some also offer longer-term programmes centred on female empowerment; train girls and others as peer educators; mentor girls after ARP; offer alternative income generation activities to ex-circumcisers, and work through

\footnotetext{
8 There are no exact figures on this, but according to the Anti-FGM Board of Kenya some 38 organisations currently run ARPs involving more than 6000 girls each year. They include NGOs, faith groups, women's groups and community-based organisations. Bernadette Loloju to Lotte Hughes (20 March 2018, email).
} 


\section{LIAS WORKING PAPER 1}

'change agents' in communities. A core theme in many ARPs is the encouragement of 'positive' culture and discouragement of 'negative' culture, though the meaning of culture is rarely explained.

\section{Kinship as the deep context of ARP}

ARP operates within deep context, which is often overlooked by their organisers. The range of practices now bundled together under the term FGM/C were historically implicated in a range of cultural practices and relational thinking linked to marriage and bridewealth exchange. Although ARP is modelled on initiatory practices aimed at girls, their design overlooks kinship, and thereby skims over the ritual process of turning girls into marriageable women. Also neglected in the design of ARP is the crucial context of bridewealth exchanges. These bind inter-marrying families with mutual obligations to protect and provide for new incoming wives. Such marital exchanges are widespread in East Africa, and are themselves undergoing important cultural changes.

To illustrate this deep context, it is worth examining the kinds of exchanges of goods, clothing, animals and cash that occur in the course of marriage transactions between families. Many Kenyans call these exchanges 'dowry', but they are more properly identified as bridewealth. Bridewealth is associated with patrilineal descent and the exchanges flow from the husband's to the wife's family. The wider context of bridewealth is vital to understanding the stakes of ARP in local marriage practices. The exchange of things and animals for persons may strike cultural outsiders as odd, but to many Kenyan communities, bridewealth is a key way of building strong marriage alliances between families within the confines of an ethnic community (Hodgson, 2000). Bridewealth is implicated in many social transactions, not only at the point when the conjugal unit is formed, but also in terms of other wider aspects of kinship such as the identities of clans and families, fathers' age-sets (Peatrik, 1999), and the living status of animals as private property and as bearers of social relations (Broch-Due, 1999). It also connects to a girl's status in terms of her practical knowledge and education (personal communication, Wamue Ngare 2018). In the largely (agro) pastoralist communities where FGM/C prevalence is high, bridewealth is a largely invisible context in the planning and organising of ARPs with effects that are likely to be significant to the abandonment of FGM/C and its relationship to marriage.

When Maasai mothers in Kajiado demonstrated in 2014 against the banning of FGM/C, arguing that this was causing Maasai men to shun their daughters and marry non-Maasai, they were in a very real sense fighting for bridewealth and kinship, the future viability of their herds and hence their community (personal communication, Parsitau 2018). An important backdrop in this kind of protest is the value of cattle (and other small-stock) to marriage transactions between Maasai families. ARPs do not incorporate any discussion about this important fact of Maasai (and other) 


\section{LIAS WORKING PAPER 1}

marriage. Similarly, with ARP's focus on the value of the educated girl, in some communities, this mitigates the possibility of obtaining new cattle to build up family herds, while in others, it actually increases the social value of a girl and leads to inflationary demands for increasingly costly and ongoing bridewealth transactions. As Lynn Thomas observes, 'Bridewealth, like female initiation, entailed material and moral exchanges that affirmed the worth and power of women's reproductive capacities' (Thomas, 2003, p. 30). This is the case among the central Kikuyu, who no longer keep herds of cattle and seek to maximise the monetary value of educated girls (personal communication, Wamue Ngare 2018).

\section{Review of the literature on ARP (see Appendix)}

The review contained in the Appendix is not exhaustive. It does not include all the existing literature; for example, it excludes internal evaluations carried out by NGOs, which are mostly unpublished. Some main points emerging from the literature include:

- Claims are often made for the 'success' of ARP without solid evidence of impact

- Methodology is often weak or inadequately described

- There is often no adequate comparison/control group

- Little or no evidence of follow-up of girls and families after ARP

- Many authors do not appear to have directly observed an ARP, including the instruction component, but rely on descriptions by other organizations at other study sites, sometimes decades earlier

- The intervention itself (ARP) is often taken as evidence of the success of the intervention.

These and other points are expanded upon in the attached linked document.

\section{Methodology and ethics}

There is a need for future research to address many audiences. It should be both qualitative and quantitative: to account for culture, power, and law, but also to establish statistical grounds for measuring the efficacy of ARP. To allow for valid estimates of the impact of ARP interventions, evaluation designs may be used which incorporate adequate comparison groups or employ other techniques for causal inference (e.g. propensity score matching).

It is too early to say what methodologies will be used, but they are likely to include interviews, focus group discussions, participant observation and desk studies including historical work in relevant archives. Records of historical interest may include missionary society collections, media articles, and the archives of organisations such as Maendeleo ya Wanawake, Amref and World 


\section{LIAS WORKING PAPER 1}

Vision. Participatory methods such as body mapping may also be a useful method. One challenge will be to identify and locate early cohorts of participants in the first ARP programmes. Using vernacular radio programmes to announce the research to the public, it may be possible to generate data from crowdsourcing through social media, leading to face-to-face focus groups.

ARPs touch upon sexuality and other topics that may not be discussed openly. It will be important to engage data collectors who have in-depth knowledge of the communities concerned, partly because sexuality and sexual reproductive health and rights (SRHR) are often spoken of indirectly, through parables, or openly only among peers (those who are about to become initiated together). It will also be important to use culturally appropriate symbolic language and images to describe the topics being discussed, so that informants are not required to talk explicitly about subjects that may be regarded as vulgar and therefore disrespectful. It may be advantageous to participants to create 'safe space' protocols for some aspects of this research. Alternatively, it may be possible to develop specific biocultural community protocols (BCPs) that safeguard participants from being adversely affected by their involvement in the research. It is advisable to engage with cultural/religious guides during research - highly respected community or religious leaders who are familiar with the cultural and religious sensibilities/politics around FGM/C and child marriage. Such people can also be used to sensitize other community leaders on the significance of the research and the importance of having community members participate and cooperate. The guides should be gender balanced, and include both elders and youth from the target population.

It is recommended that data collectors and interviewers from local communities are given participatory training and are involved in co-creating questionnaires and interview tools on FGM/C. It is a goal of this research network to foster and encourage research capacity within community settings. A research training protocol that would facilitate sustainable research skills would empower participants in their responses to future work on FGM/C abandonment and the search for alternatives. This would help to avoid researcher bias and pitfalls, as well as give local people more of a sense of ownership of the research process, and create greater understanding of the benefits of research to the target population.

\subsection{Ethics}

Informed and Prior Consent protocols will be followed. Research aims, methods, and risks will be explained at the outset, in accessible and appropriate language, and consent obtained either orally (which may be more appropriate in societies where signed consent forms are not easily understood), and noted or recorded, or obtained in writing. Informants must be offered anonymity, though it is understood that not everyone will wish to be anonymised, e.g. activists, 


\section{LIAS WORKING PAPER 1}

community leaders, faith leaders. It may also be necessary to redact the name of the village or community concerned, and to change other identifying features, in order to protect informants. Data will be archived securely in an external archive such as the UK Data Service, and its Kenyan equivalent.

\section{Some other topics for future research}

Workshop participants identified several possible future lines of enquiry, which include:

- The wider significance and symbolism of girls' initiation, which tends to be overlooked in cut-centred campaigns against FGM/C

- The unsustainability of ARP, for reasons including NGO funding, donor unpredictability, communities' lack of capacity or unwillingness to take over responsibility for it

- The need to involve boys and men more in ARP and other efforts to end FGM/C

- Tracking the international funding trail for ARP: who funds it, where and why?

- Risk to vulnerable girls of short-term interventions and inadequate follow-on support

- Finding hard evidence of FGM/C abandonment post-ARP

- The role of faith leaders and churches in ARP

- Historical antecedents, e.g. the 'female circumcision crisis' in colonial Kenya

- Following up the cohort of girls who first underwent ARP in the late 1990s in Kenya how did their lives turn out? Did they and their daughters manage to resist FGM/C?

- The need to follow up on other cohorts of girls, e.g. in the Kikuyu community, who have abandoned FGM/C without ARP.

We welcome comments on this paper, which aims to open up discussion among a wide range of stakeholders on this important topic. Please contact: $\underline{\text { lias@le.ac.uk }}$ 


\section{LIAS WORKING PAPER 1}

\section{References (including those in the literature review table)}

Broch-Due, V. (2000). 'Remembered cattle, forgotten people'. In: D. M. Anderson and V. Broch-Due, eds. The Poor Are Not Us: Poverty and pastoralism in Eastern Africa. Oxford: James Currey.

Buttia, C. (2015). Investigation of successful interventions in mitigation of female genital mutilation/ cutting (FGM/C) among selected Kenyan communities: Maasai, Kisii and Kuria. Masters. Hamburg University of Applied Sciences.

Chege, J.N., Askew, I. and Liku, J. (2001). An assessment of the alternative rites approach for encouraging abandonment of female genital mutilation in Kenya. Washington DC: FRONTIERS in Reproductive Health and Population Council.

Döcker, M. (2011). Overcoming female genital cutting. An examination of approaches to overcome the harmful traditional practice: A children's rights perspective. Masters. Freie Universität.

Esho, T., Karumbi, J. and Njue, C. (2017). Rapid evidence assessment: Quality of studies assessing interventions to support FGM/C abandonment. Evidence to End FGM/C Programme: Research to Help Girls and Women Thrive. New York: Population Council.

Galukande, M., Kamara, J., Ndabwire, V., Leistey, E., Valla, C. and Luboga, S. (2015). Eradicating Female Genital Mutilation and Cutting in Tanzania: An observational study. BMC Public Health, 15(1147), pp. 1-10.

Gitagno, J.F. (2015). Effects of alternative rite of passage on girls' education among the Keiyo community of Elgeyo Marakwet County, Kenya. Masters. Egerton University.

Hernlund, Y. and Shell-Duncan, B. (2007). Contingency, Context, and Change: Negotiating female genital cutting in The Gambia and Senegal. Africa Today, 52(4), pp. 43-57.

Hodgson, D. L. (2000). 'Pastoralism, patriarchy \& history among Maasai in Tanganyika 18901940’. In: D.L. Hodgson, ed., Rethinking Pastoralism in Africa. Oxford: James Currey.

Hughes, L. (2018). Alternative Rites of Passage: Faith, rights, and performance in FGM/C abandonment campaigns in Kenya. African Studies, 77(2), pp.274-292.

Ingdal, N., Umbima, J. and Tysse, A. L. (2008). Mid-term review of project. Practice reduction and awareness on female genital mutilation (FGM). Nairobi and Oslo: Y Global and Forum for Women and Development (FOKUS). YWCA Kenya.

Lokurosia, J.C. (2011). An assessment of the impact of health campaigns against female genital mutilation in West Pokot District, Kenya. Masters. Kenyatta University. 


\section{LIAS WORKING PAPER 1}

Kassim, S.S. (2014). The attitudes of Maasai parents towards Alternative Rites of Passage of girls in Central Division, Narok County, Kenya. Masters. University of Nairobi.

Lie, G.T., Lothe, E.A. and Ali, C. (2004). Working against Female Genital Mutilation, Tanzania. A qualitative evaluation. Oslo: Kvinnefronten/Women's Front of Norway.

Mepukori, D.N. (2016). Is Alternative Rites of Passage the key to abandonment of female genital cutting? A case study of the Samburu of Kenya. BA. Duke University.

Mitchell, L. and Eke, C. (n.d.). Alternatives to female genital mutilation in Western Africa. Available at:

http://web.stanford.edu/group/womenscourage/FGM/chibuzo lily FGM paper.html [Accessed 2 April 2018]

M'Raiji, J.K. (2015). The transformation of Swabili unyago and female genital mutilation into an Alternative Rite of Passage: A poststructuralist approach. PhD. University of Botswana.

Muteshi, J. and Sass, J. (2005). Female genital mutilation in Africa. An analysis of current abandonment approaches. Nairobi: PATH.

Nambisia, E. (2014). Measures influencing eradication of female genital mutilation practices among the Maasai community in Maparasha constituency, Kajiado County, Kenya. Masters. University of Nairobi.

Namulondo, J. (2009). A case of the Sabiny in Kapchowra District, Uganda. MA. Universities of Trømso, Gothenburg and Roehampton.

Olenja, J. (2000). Eliminating the practice of female genital mutilation: Awareness-raising and community change in four districts of Kenya. Nairobi: PATH and MYWO.

Oloo, H., Wanjiru, M. and Newell-Jones, K. (2011). Female genital mutilation practices in Kenya: The role of Alternative Rites of Passage. A case study of Kisii and Kuria Districts. London: Feed the Minds.

O'Neill, S. (2012). Defying the law, negotiating change. The Futanke's opposition to the national ban on FGM in Senegal. PhD. University of London.

Peatrik, A. M. (1999). La Vie à Pas Contés: Génération, âge et société dans les Hautes Terres du Kénya (Meru Tigania-Igembe). Nanterre: Société d'ethnologie.

Prazak, M. (2007). Introducing Alternative Rites of Passage. Africa Today, 53(4), pp.19-40. 
Soneya, J. M.; Biwott, J. C. and Kangogo, W. J. (2009). Evaluation Report for the Anti Female Genital Mutilation Maasai (FGM) Project. Oslo: NORAD.

Thomas, L. M. (2003). Politics of the Womb: Women, reproduction, and the state in Kenya. Oakland, CA: University of California Press.

28toomany (2013). Country Profile: FGM in Uganda. London: 28toomany.

Waritay, J. and Wilson, A-M. (2013). Working to End Female Genital Mutilation and Cutting in Tanzania. The Role and Response of the Church. London: TEARFUND.

UNFPA/UNICEF (2013). Joint Evaluation of the UNFPA-UNICEF Joint Programme on Female Genital Mutilation / Cutting (FGM/C): Accelerating Change (2008-2012). Country Case Study: Kenya. No place of publication given.

World Bank/UNFPA (2004). Female genital mutilation/cutting in Somalia. No place of publication. World Health Organization/PATH (1999). Female genital mutilation. Programmes to date: What works and what doesn't. A review. Geneva: WHO.

\section{About the authors}

- Lawrence Droy is a PhD candidate at the University of Leicester, studying FGM/C

- Lotte Hughes is an historian and independent scholar, who researches ARP and FGM/C in Kenya

- Mark Lamont is an anthropologist, who researches male gender violence linked to forced male circumcision in Kenya. He currently works for the British Institute of East Africa

- Peter Nguura is Interim Director, Anti-FGM Centre of Excellence, Amref Health Africa, Nairobi

- Damaris Parsitau is Director of the Institute of Women Gender and Development Studies, Egerton University, Kenya

- Grace Wamue Ngare is an Assoc. Professor in the Department of Gender and Development Studies, Kenyatta University, Kenya 


\section{Appendix: Review of ARP Evaluation Studies}

This is not an exhaustive survey of the existing published literature which mentions ARP, but focuses on more substantive mentions. The authors would welcome notification of other literature that includes substantive discussion and analysis of ARP in Africa, especially that drawing on primary data. All study sites are in Kenya unless otherwise stated. (See References for full citations.)

\section{Terminology \& Acronyms}

Baseline survey $=$ Survey undertaken before the intervention

Comparison group = A comparable group of respondents who have not gone through the intervention

Comparison site $=$ Site without anti-FGM/C advocacy/activities being evaluated

Control group $=$ A comparison group rendered comparable to the intervention group by random allocation

CEDPA $=$ Centre for Development and Population Activities

Endline survey $=$ Survey undertaken after the intervention

FGD $=$ focus group discussion

FPFK $=$ Free Pentecostal Fellowship of Kenya

$\mathbf{H R}=$ human rights

ICRW = International Center for Research on Women

Intervention group $=$ A group of respondents who have been (potentially) affected by the intervention under evaluation

Intervention site $=$ Site of the anti-FGM $/ \mathrm{C}$ advocacy $/$ activities being evaluated

$\mathbf{i} / \mathbf{v}=$ interview

KDHS $=$ Kenya Health and Demographic Survey

MYWO = Maendeleo ya Wanawake (Kenyan women's development organization)

PATH $=$ Program for Alternative Technology in Health

REACH $=$ Reproductive, Education and Community Health Project (Ugandan NGO)

WVK $=$ World Vision Kenya; World Vision Germany also cited once 


\begin{tabular}{|c|c|c|c|c|c|c|}
\hline Study & $\begin{array}{l}\text { Study site / } \\
\text { ethnic group }\end{array}$ & $\begin{array}{l}\text { ARP specific } \\
\text { interventions }\end{array}$ & $\begin{array}{l}\text { Non-ARP specific } \\
\text { interventions }\end{array}$ & Methodology / Sampling & $\begin{array}{l}\text { How Practice Was } \\
\text { Measured }\end{array}$ & $\begin{array}{l}\text { Notes on } \\
\text { Outcomes }\end{array}$ \\
\hline $\begin{array}{l}\text { Buttia (2015) } \\
\text { (thesis) }\end{array}$ & $\begin{array}{l}\text { Maasai (Kenya \& } \\
\text { Tanzania), Kisii, } \\
\text { Kuria }\end{array}$ & $\begin{array}{l}\text { Instruction for } \\
\text { girls; public } \\
\text { graduation } \\
\text { ceremony }\end{array}$ & $\begin{array}{l}\text { Community sensitization; } \\
\text { school forums; female } \\
\text { empowerment; campaigns; } \\
\text { rescue centres \& camps; } \\
\text { engaging faith leaders }\end{array}$ & Lit review, no primary data & $\begin{array}{l}\text { Sources on prevalence are } \\
\text { mostly KDHS (2008-09), } \\
\text { which does not give } \\
\text { breakdown by ethnic group, } \\
\text { only by region (former } \\
\text { provinces). Nyanza Province, } \\
\text { as it then was, whose } \\
\text { population includes Luo, } \\
\text { Kisii, Kuria, had 33.8\% } \\
\text { prevalence in } 2008-09\end{array}$ & $\begin{array}{l}\text { Claims ARP \& } \\
\text { 'broad-based } \\
\text { approach involving } \\
\text { the whole } \\
\text { community' has } \\
\text { reduced FGM. No } \\
\text { quantitative evidence }\end{array}$ \\
\hline $\begin{array}{l}\text { Chege, Askew, } \\
\text { Liku (2001) }\end{array}$ & $\begin{array}{l}\text { Tharaka (Meru), } \\
\text { Narok (Kalenjin \& } \\
\text { Maasai) \& Gucha } \\
\text { (Abagusii) } \\
\text { Districts }\end{array}$ & $\begin{array}{l}\text { Instruction for } \\
\text { girls in seclusion; } \\
\text { public ceremony } \\
\text { inc. declarations } \\
\text { of abandonment } \\
\text { Conducted with } \\
\text { girls who didn't } \\
\text { want to be cut or } \\
\text { whose parents } \\
\text { didn't want them } \\
\text { to be cut }\end{array}$ & $\begin{array}{l}\text { Community sensitization/ } \\
\text { education; peer educators } \\
\text { trained; FGDs on current } \\
\text { practice }\end{array}$ & $\begin{array}{l}\text { Household surveys of } 601 \\
\text { families with a daughter recorded } \\
\text { as having undergone ARP. } \\
\text { Results compared with clustered } \\
\text { random sample of } 600 \text { families } \\
\text { from same districts whose girls } \\
\text { had not undergone ARP } \\
\text { After the intervention: } 37 \text { FGDs } \\
\text { held with trainers \& community } \\
\text { members; } 53 \text { i/vs with NGO } \\
\text { staff, community leaders \& } \\
\text { circumcisers; } 9 \text { case studies of } \\
\text { families whose girls underwent } \\
\text { ARP }\end{array}$ & $\begin{array}{l}\text { Changes in prevalence } \\
\text { between age cohorts in } \\
\text { different ethnic groups in } \\
\text { secondary aggregate survey } \\
\text { data } \\
\text { Intentions of boys and girls } \\
\text { to circumcise their daughters } \\
\text { in the future } \\
\text { Beliefs of boys, girls, mothers } \\
\text { and fathers about whether } \\
\text { FGM/C should continue } \\
\text { Circumcision status of } \\
\text { daughters aged } 15 \text { and above }\end{array}$ & $\begin{array}{l}\text { FGDs among } \\
\text { Abagusii \& Maasai } \\
\text { reported no general } \\
\text { decline in prevalence. } \\
\text { Discussions among } \\
\text { Meru \& Mulot } \\
\text { suggested some } \\
\text { recent decline } \\
\text { Many parents may } \\
\text { have decided to } \\
\text { abandon FGM/C } \\
\text { before the } \\
\text { intervention activities } \\
\text { began }\end{array}$ \\
\hline
\end{tabular}




\begin{tabular}{|c|c|c|c|c|c|c|}
\hline $\begin{array}{l}\text { Döcker (2011) } \\
\text { (thesis, for WV } \\
\text { Germany) }\end{array}$ & $\begin{array}{l}\text { Marigat District } \\
\text { (IlChamus, } \\
\text { Kalenjin, a few } \\
\text { others). Study also } \\
\text { more briefly } \\
\text { discusses } \\
\text { interventions in } \\
\text { other areas, inc. } \\
\text { MYWO ARPs in } \\
\text { Meru (1996) }\end{array}$ & $\begin{array}{l}\text { Instruction for } \\
\text { girls; ceremony } \\
\text { with public } \\
\text { declaration of } \\
\text { abandonment }\end{array}$ & $\begin{array}{l}\text { Community sensitization \& } \\
\text { education; school clubs; } \\
\text { training for boys; rescue } \\
\text { centres; income generation } \\
\text { for ex-circumcisers }\end{array}$ & $\begin{array}{l}\text { Quantitative \& qualitative } \\
\text { baseline surveys inc. household } \\
\text { (no mention of endline surveys), } \\
\text { FGDs, key informant i/vs } \\
\text { (WVK data, nos not given). } 139 \\
\text { girls \& } 161 \text { boys given } \\
\text { questionnaire in school setting } \\
\text { (not clear if author wrote this). } \\
\text { No comparison/control group }\end{array}$ & $\begin{array}{l}\text { Author did not measure } \\
\text { practice, cites WVK figures } \\
\text { from external consultant's } \\
\text { evaluation. Baseline survey } \\
\text { showed district prevalence } \\
\text { was } 94.29 \% \text { (WVK 2006) }\end{array}$ & $\begin{array}{l}64 \% \text { of boys \& } 71 \% \\
\text { of girls polled think } \\
\text { ARP can replace } \\
\text { cutting (according to } \\
\text { questionnaire). } \\
\text { Author admits school } \\
\text { environment } \\
\text { influenced answers. } \\
\text { WVK claims } \\
\text { prevalence fell } 36 \% \text { in } \\
5 \text { years in survey pop- } \\
\text { ulation; attitudes to } \\
\text { FGM/C changed; } \\
\text { school enrolment \& } \\
\text { retention rates rose, } \\
\text { etc. But few before \& } \\
\text { after figures given. } \\
\text { Some 'outcomes' } \\
\text { confused with NGO } \\
\text { project goals }\end{array}$ \\
\hline $\begin{array}{l}\text { Galukande et } \\
\text { al. (2015) }\end{array}$ & $\begin{array}{l}\text { Arusha region, } \\
\text { Tanzania } \\
\text { (predominantly } \\
\text { Maasai) }\end{array}$ & $\begin{array}{l}\text { Instruction for } \\
\text { girls; ceremony } \\
\text { with public } \\
\text { declaration of } \\
\text { abandonment }\end{array}$ & $\begin{array}{l}\text { Community education, } \\
\text { sensitization \& dialogues; } \\
\text { school health clubs; } \\
\text { economic support for ex- } \\
\text { circumcisers; training youth, } \\
\text { warriors, ex-circumcisers }\end{array}$ & $\begin{array}{l}\text { Baseline \& endline surveys were } \\
\text { administered to a systematic } \\
\text { sample of households in the } \\
\text { intervention area. Key informant } \\
\text { i/vs, FGDs, group discussions } \\
\text { with school children, document } \\
\text { reviews were also used. No } \\
\text { comparison/control group }\end{array}$ & $\begin{array}{l}\text { Practice was self-reported by } \\
\text { participants, \& compared to } \\
\text { obstetric examination of } \\
\text { women in labour }\end{array}$ & $\begin{array}{l}\text { Contradictory } \\
\text { prevalence estimates } \\
\text { from self-reported } \\
\text { and examined } \\
\text { FGM/C status: } \\
69.2 \% \text { self-reported } \\
\text { compared to } 95 \%+ \\
\text { among women in } \\
\text { labour who were phy- } \\
\text { sically examined }\end{array}$ \\
\hline $\begin{array}{l}\text { Gitagno (2015) } \\
\text { (thesis) }\end{array}$ & $\begin{array}{l}\text { Keiyo people, } \\
\text { Elgeyo- } \\
\text { Marakwet County }\end{array}$ & $\begin{array}{l}\text { Girls' training in } \\
\text { seclusion; public } \\
\text { ceremony? (not } \\
\text { clearly stated) }\end{array}$ & $\begin{array}{l}\text { Community sensitization \& } \\
\text { education inc. seminars on } \\
\text { ARP }\end{array}$ & $\begin{array}{l}155 \text { girls who had undergone } \\
\text { ARP identified via 'purposive } \\
\text { sampling'. Data collection } \\
\text { methods included questionnaires, } \\
\text { i/vs, FGDs with community } \\
\text { leaders \& elders. No comparison } \\
\text { group, or baseline \& endline } \\
\text { surveys }\end{array}$ & $\begin{array}{l}\text { No prevalence rate given for } \\
\text { Keiyo community }\end{array}$ & $\begin{array}{l}\text { Most ARP graduates } \\
\text { want FGM/C to end; } \\
\text { ARP said to have } \\
\text { been accepted by } \\
\text { community to replace } \\
\text { traditional rite; ARP } \\
\text { has 'contributed } \\
\text { positively' to girls' }\end{array}$ \\
\hline
\end{tabular}


LIAS WORKING PAPER 1

\begin{tabular}{|c|c|c|c|c|c|c|}
\hline & & & & & & $\begin{array}{l}\text { education. But } \\
\text { 'mechanisms that } \\
\text { sustain ... FGM/C } \\
\text { are still firmly rooted } \\
\text { in the culture' }\end{array}$ \\
\hline $\begin{array}{l}\text { Ingdal et al. } \\
(2008) \\
\text { (for YWCA } \\
\text { Kenya) }\end{array}$ & $\begin{array}{l}\text { Meru, Kisii \& } \\
\text { Kajiado Districts }\end{array}$ & $\begin{array}{l}\text { Instruction for } \\
\text { girls; public } \\
\text { ceremony } \\
\text { (neither } \\
\text { witnessed by } \\
\text { authors) }\end{array}$ & $\begin{array}{l}\text { Training of trainers; rescue } \\
\text { 'shelters'; income generation } \\
\text { for ex-circumcisers }\end{array}$ & $\begin{array}{l}\text { Lit review, desk study of project } \\
\text { documents; i/vs, FGDs with } 130 \\
\text { 'beneficiaries' inc. girls, women, } \\
\text { boys, local \& national authorities, } \\
\text { community leaders. No baseline } \\
\text { or endline surveys (YWCA } \\
\text { planned baseline survey in 2009). } \\
\text { Study used an assessment matrix } \\
\text { to assess project using } 5 \text { criteria: } \\
\text { relevance, effectiveness, } \\
\text { efficiency, sustainability \& } \\
\text { partnership }\end{array}$ & $\begin{array}{l}\text { No prevalence rates given for } \\
\text { the specific communities } \\
\text { targeted in interventions }\end{array}$ & $\begin{array}{l}\text { Authors query why } \\
\text { Kisii girls as young as } \\
5-6 \text { had taken part in } \\
\text { ARP. No direct } \\
\text { evidence of change in } \\
\text { attitudes to FGM/C } \\
\text { or practice. Girls said } \\
\text { to be 'much } \\
\text { empowered' after } \\
\text { ARP, a few ex- } \\
\text { circumcisers acting as } \\
\text { good role models, } \\
\text { some local chiefs } \\
\text { 'speaking out'. } \\
\text { YWCA criticised for } \\
\text { spending too much } \\
\text { on rescue shelters, \& } \\
\text { poor documentation; } \\
\text { no written records of } \\
\text { how ARP was } \\
\text { organised }\end{array}$ \\
\hline Kassim (2014) & $\begin{array}{l}\text { Maasai, Narok } \\
\text { County }\end{array}$ & $\begin{array}{l}\text { Not fully } \\
\text { described. } \\
\text { Instruction for } \\
\text { girls in seclusion; } \\
\text { public ceremony. } \\
\text { Says 'public ritual' } \\
\text { includes girls' } \\
\text { training, but this } \\
\text { is never held in } \\
\text { public }\end{array}$ & $\begin{array}{l}\text { Community sensitization \& } \\
\text { education; rescue centres; use } \\
\text { of peer educators }\end{array}$ & $\begin{array}{l}\text { Primary data gathered via FGDs } \\
\text { (separate ones for parents of } \\
\text { both genders, girls), key } \\
\text { informant i/vs. No baseline or } \\
\text { endline surveys mentioned. } \\
\text { Author used systematic random } \\
\text { sampling }\end{array}$ & $\begin{array}{l}\text { Not stated for this specific } \\
\text { community, only for Kenya }\end{array}$ & $\begin{array}{l}\text { Most educated } \\
\text { parents surveyed } \\
\text { preferred ARP over } \\
\text { rites involving } \\
\text { FGM/C. But } 60 \% \text { of } \\
\text { parents strongly } \\
\text { agreed it was } \\
\text { important for girls to } \\
\text { go through FGM/C }\end{array}$ \\
\hline
\end{tabular}


LIAS WORKING PAPER 1

\begin{tabular}{|c|c|c|c|c|c|c|}
\hline $\begin{array}{l}\text { Lie, Lothe \& Ali } \\
\text { (2004) }\end{array}$ & Tanzania (various) & $\begin{array}{l}\text { Training, public } \\
\text { celebration }\end{array}$ & $\begin{array}{l}\text { Community } \\
\text { sensitization/mobilization, } \\
\text { advocacy }\end{array}$ & $\begin{array}{l}\text { Individual and group qualitative } \\
\text { interviews were conducted with a } \\
\text { purposive sample of informants } \\
\text { (including NGO staff, youth, ex- } \\
\text { circumcisers) in a range of } \\
\text { purposively selected study sites. } \\
\text { No baseline survey, no } \\
\text { comparison group }\end{array}$ & $\begin{array}{l}\text { Respondent reports about } \\
\text { their own practice and/or } \\
\text { practice of others in the } \\
\text { community }\end{array}$ & \\
\hline $\begin{array}{l}\text { Lokurosia } \\
(2006)\end{array}$ & $\begin{array}{l}\text { West Pokot } \\
\text { (intervention site: } \\
\text { Chepareria } \\
\text { Division; } \\
\text { comparison site: } \\
\text { Sigor Division) }\end{array}$ & $\begin{array}{l}\text { Instruction \& } \\
\text { seclusion of girls; } \\
\text { public ceremony } \\
\text { inc. declaration of } \\
\text { abandonment }\end{array}$ & $\begin{array}{l}\text { Community education \& } \\
\text { awareness-raising on HR, } \\
\text { health, etc; mobilization of } \\
\text { community leaders }\end{array}$ & $\begin{array}{l}375 \text { household heads identified } \\
\text { through a random sample of } \\
\text { households in a district with a } \\
\text { history of intervention efforts } \\
\text { were interviewed and participated } \\
\text { in FGDs. Their responses were } \\
\text { compared to a sample of } 375 \\
\text { household heads in a comparison } \\
\text { site without a history of } \\
\text { intervention efforts. No baseline } \\
\text { measurement at either site }\end{array}$ & $\begin{array}{l}\text { Respondents rated } \\
\text { prevalence of FGM/C in } \\
\text { their communities } \\
\text { (Commonly Practiced, Rarely } \\
\text { Practiced, etc.). Female } \\
\text { respondents self-reported } \\
\text { FGM/C status. Household } \\
\text { heads reported their } \\
\text { daughters' status }\end{array}$ & $\begin{array}{l}\text { The popularity and } \\
\text { practice of FGM/C } \\
\text { was lower in the } \\
\text { intervention site than } \\
\text { the comparison site. } \\
\text { Prior equivalence of } \\
\text { sites not established }\end{array}$ \\
\hline $\begin{array}{l}\text { Masas (2009) } \\
\text { (for FPFK } \\
\text { church) }\end{array}$ & $\begin{array}{l}\text { Maasai in } 4 \\
\text { districts of } \\
\text { Southern Rift } \\
\text { (Pentecostal } \\
\text { church-goers) }\end{array}$ & $\begin{array}{l}\text { Not described, } \\
\text { apparently not } \\
\text { witnessed }\end{array}$ & $\begin{array}{l}\text { Community } \\
\text { sensitization/education; } \\
\text { women's group meetings; } \\
\text { church forums; use of drama } \\
\text { \& other arts }\end{array}$ & $\begin{array}{l}\text { Mid-term evaluation of project } \\
\text { after } 1 \text { year. No mention of } \\
\text { baseline or endline surveys. I/vs } \\
\text { with church board \& staff, girls, } \\
\text { parents, teachers, other } \\
\text { community stakeholders; FGDs }\end{array}$ & $\begin{array}{l}\text { Not stated for this specific } \\
\text { community }\end{array}$ & $\begin{array}{l}\text { Reports } 60 \% \text { of } \\
\text { church community } \\
\text { have stopped } \\
\text { FGM/C. } \\
\text { Recommends } \\
\text { stakeholders write a } \\
\text { document describing } \\
\text { an 'acceptable \& } \\
\text { sustainable ARP } \\
\text { procedure' }\end{array}$ \\
\hline $\begin{array}{l}\text { Mepukori } \\
\text { (2016) (thesis }\end{array}$ & Samburu County & $\begin{array}{l}\text { Instruction for } \\
\text { girls; public } \\
\text { ceremony inc. }\end{array}$ & $\begin{array}{l}\text { Community sensitization; } \\
\text { training peer educators; }\end{array}$ & $\begin{array}{l}\text { FGDs with elders, women, girls } \\
\text { who had undergone ARP, } \\
\text { beaded girls; }{ }^{9} \text { key informant i/vs; }\end{array}$ & $\begin{array}{l}\text { Author did not measure or } \\
\text { cite prevalence in specific } \\
\text { community }\end{array}$ & $\begin{array}{l}\text { There is insufficient } \\
\text { community 'buy-in' } \\
\text { for ARP to succeed. }\end{array}$ \\
\hline
\end{tabular}

9 The beading of girls is a 'traditional' practice in the Samburu community that involves uncircumcised girls aged 9 or 10 being promised to young warriors as girlfriends. A warrior sells livestock in order to buy beads which he gives to the girl he is interested in. The girl's father then permits the warrior to have intercourse with the girl in a special hut built by the father, whenever he visits. Source: Mepukori (2016, p. 26, note 13). 
LIAS WORKING PAPER 1

\begin{tabular}{|c|c|c|c|c|c|c|}
\hline $\begin{array}{l}\text { on Amref } \\
\text { ARPs) }\end{array}$ & & $\begin{array}{l}\text { declaration of } \\
\text { abandonment, } \\
\text { elders' blessings }\end{array}$ & $\begin{array}{l}\text { support forums for mothers } \\
\& \text { girls }\end{array}$ & $\begin{array}{l}\text { observation of Amref training } \\
\text { sessions (does not say who for) } \\
\text { \& assessments of women's } \\
\text { groups. Used 'purposive } \\
\text { sampling' to identify informants. } \\
\text { Compared Samburu practices } \\
\text { with non-cutting Turkana (in } \\
\text { women's group discussion). No } \\
\text { baseline or endline surveys }\end{array}$ & & $\begin{array}{l}\text { Politicians identified } \\
\text { as a major stumbling } \\
\text { block in fight against } \\
\text { FGM/C }\end{array}$ \\
\hline $\begin{array}{l}\text { Muteshi \& Sass } \\
(2005) \\
(\text { for PATH })\end{array}$ & $\begin{array}{l}\text { Africa (ARP only } \\
\text { described for } \\
\text { Kenya, Gambia. } \\
\text { Very brief } \\
\text { mention of } \\
\text { Uganda) }\end{array}$ & $\begin{array}{l}\text { Life-skills } \\
\text { education in } \\
\text { seclusion for } \\
\text { girls; public } \\
\text { ceremony } \\
\text { (Kenya). } \\
\text { Gambian ARPs } \\
\text { not described but } \\
\text { local NGO has } \\
\text { built permanent } \\
\text { site for } \\
\text { ceremonies }\end{array}$ & $\begin{array}{l}\text { Community sensitization, } \\
\text { awareness-raising, education; } \\
\text { engagement with faith } \\
\text { leaders; training ex- } \\
\text { circumcisers; women, youth } \\
\text { \& men trained as peer } \\
\text { educators (Kenya). In } \\
\text { Gambia NGO set up } \\
\text { committee of faith leaders to } \\
\text { support anti-FGM/C efforts }\end{array}$ & $\begin{array}{l}\text { No primary data collected, } \\
\text { reviewed existing data. Kenya } \\
\text { baseline survey by } \\
\text { MYWO/PATH (1996) in } 4 \\
\text { districts. Evaluation } 5 \text { years later } \\
\text { found none of the nearly } 5000 \\
\text { graduates had later undergone } \\
\text { FGM/C (not clear if endline } \\
\text { survey was conducted by same } \\
\text { NGOs), authors cite unpublished } \\
\text { paper, Folsom } 2003 \text { ). } \\
\text { Gambia: NGO carried out } \\
\text { baseline survey in } 2 \text { areas (1996). } \\
\text { Results shared with community } \\
\text { leaders. No details of surveys, } \\
\text { measurement or sampling }\end{array}$ & $\begin{array}{l}\text { Kenya figures are from } \\
\text { Demographic Health Surveys } \\
\text { (DHS): 38\% (1998), 32\% } \\
\text { (2003). DHS had not } \\
\text { included Qs on FGM/C for } \\
\text { Gambia \& Uganda by mid- } \\
\text { 2005. More than 70\% of } \\
\text { Gambian girls/women said } \\
\text { to have undergone FGM/C } \\
\text { (ICRW/CEDPA 1999). } \\
\text { Fewer Gambian girls cut at } \\
\text { intervention site after ARP } \\
\text { (comparing } 1996 \text { figures with } \\
\text { 1997). 78\% of Gambian } \\
\text { women surveyed favoured } \\
\text { ending FGM/C (1997) } \\
\text { compared to 30-40\% (1996, } \\
\text { op. cit.) }\end{array}$ & $\begin{array}{l}\text { Referring to the } 3 \\
\text { countries: positive } \\
\text { change in attitudes to } \\
\text { \& practice of } \\
\text { FGM/C attributed to } \\
\text { the intervention. } \\
\text { 'ARP approaches } \\
\text { have been successful } \\
\text { because of their } \\
\text { comprehensive } \\
\text { nature' (p.29). The } \\
\text { approach must } \\
\text { involve both parents } \\
\text { \& village leaders to } \\
\text { ensure buy-in }\end{array}$ \\
\hline Nambisia (2014) & $\begin{array}{l}\text { Maasai, Kajiado } \\
\text { County }\end{array}$ & $\begin{array}{l}\text { Some } \\
\text { respondents } \\
\text { reported that } \\
\text { ARP seclusion \& } \\
\text { training, \& public } \\
\text { ceremonies with } \\
\text { speeches \& gifts, } \\
\text { had taken place in } \\
\text { their village. } \\
\text { No details }\end{array}$ & $\begin{array}{l}\text { Community sensitization; } \\
\text { rescue centres; legal } \\
\text { enforcement \& legal } \\
\text { education had reportedly } \\
\text { taken place in some villages. } \\
\text { No details of specific } \\
\text { activities }\end{array}$ & $\begin{array}{l}\text { A stratified random sample of } \\
\text { individuals in a village in Kajiado } \\
\text { County were surveyed yielding } \\
228 \text { respondents (men, women \& } \\
\text { children). No pre-intervention } \\
\text { data or (non-intervention) } \\
\text { comparison group }\end{array}$ & $\begin{array}{l}\text { Respondents' reports on } \\
\text { whether FGM/C had } \\
\text { declined }\end{array}$ & $\begin{array}{l}\text { The majority of } \\
\text { participants agreed } \\
\text { that FGM/C had } \\
\text { declined; a majority } \\
\text { disagreed that ARP } \\
\text { did not comply with } \\
\text { Maasai culture }\end{array}$ \\
\hline
\end{tabular}


LIAS WORKING PAPER 1

\begin{tabular}{|c|c|c|c|c|c|c|}
\hline Olenja (2000) & $\begin{array}{l}\text { Kisii, Meru, Narok } \\
\text { \& Samburu }\end{array}$ & $\begin{array}{l}\text { Not described in } \\
\text { detail: implies } \\
\text { public graduation } \\
\text { ceremony and } \\
\text { some form of } \\
\text { education }\end{array}$ & $\begin{array}{l}\text { Peer educators; mobilising } \\
\text { opinion leaders; media } \\
\text { outreach; behaviour change } \\
\text { communication; education; } \\
\text { capacity building; } \\
\text { intergenerational debate }\end{array}$ & $\begin{array}{l}\text { Baseline \& endline surveys } \\
\text { (sampling strategy not clearly } \\
\text { described) were undertaken in a } \\
\text { range of purposely selected } \\
\text { intervention sites. Endline survey } \\
\text { included 'project' and } \\
\text { comparison ('non-project') sites } \\
\text { in } 4 \text { regions where the project } \\
\text { had been active. I/vs with key } \\
\text { informants (e.g. peer educators) }\end{array}$ & $\begin{array}{l}\text { Women's self-reported } \\
\text { FGM/C status. Reported } \\
\text { status of female \& male } \\
\text { respondents' daughters, } \\
\text { reported status of } \\
\text { respondents' mothers. Men's } \\
\text { reported FGM/C status of } \\
\text { close female relatives }\end{array}$ & $\begin{array}{l}\text { Reduction in practice } \\
\text { of FGM/C after the } \\
\text { intervention in the } \\
\text { study sites }\end{array}$ \\
\hline $\begin{array}{l}\text { Oloo et al. } \\
(2011)\end{array}$ & Kisii, Kuria & $\begin{array}{l}\text { Girls' instruction } \\
\text { \& empowerment } \\
\text { programme; } \\
\text { public ceremony } \\
\text { (Kisii). Rescue } \\
\text { camps with some } \\
\text { training \& ARP } \\
\text { graduation } \\
\text { ceremony (Kuria) }\end{array}$ & $\begin{array}{l}\text { Community awareness- } \\
\text { raising \& education; work in } \\
\text { schools, with health } \\
\text { providers, faith leaders, } \\
\text { community leaders }\end{array}$ & $\begin{array}{l}20 \text { FGDs (up to } 12 \text { people per } \\
\text { group) with a purposive sample } \\
\text { of respondents from key } \\
\text { stakeholder groups (e.g. mothers } \\
\text { whose daughters went through } \\
\text { ARP, community leaders, etc.) in } \\
\text { Kisii and Kuria. } 10 \text { key informant } \\
\text { i/vs conducted with a purposive } \\
\text { sample of key anti-FGM/C } \\
\text { organisations and other } \\
\text { individuals involved with } \\
\text { FGM/C or anti-FGM/C } \\
\text { activities. No baseline data }\end{array}$ & $\begin{array}{l}\text { Respondent reports about } \\
\text { their own practice and/or the } \\
\text { practice of others in the } \\
\text { community }\end{array}$ & $\begin{array}{l}\text { Many in Kuria critical } \\
\text { of ARP/rescue } \\
\text { camps. Some girls } \\
\text { went home and were } \\
\text { cut after the camp/s. } \\
\text { Efforts in Kisii were } \\
\text { considered more } \\
\text { effective }\end{array}$ \\
\hline Prazak (2007) & Kuria District & $\begin{array}{l}\text { Workshops for } \\
\text { girls; public } \\
\text { ceremony where } \\
\text { girls were given } \\
\text { certificates of } \\
\text { attendance }\end{array}$ & Not described & $\begin{array}{l}\text { Author cites answers to opinion } \\
\text { polls she gave Standard } 8 \text { pupils } \\
\text { in 1988, } 1993 \text { \& } 2003 \text { ( } 226 \text { girls } \\
\text { in total, } 432 \text { boys, average age } \\
\text { 15/16). No primary data on } \\
\text { ARP; author did not set out to } \\
\text { collect it }\end{array}$ & See previous column & $\begin{array}{l}\text { Youth have thought } \\
\text { FGM/C unnecessary } \\
\text { since 1988; girls } \\
\text { favour it more than } \\
\text { boys (poll results). } \\
\text { Most } 2004 \text { ARP } \\
\text { graduates in district } \\
\text { later forced to } \\
\text { undergo FGM/C } \\
\text { (209 out of } 289 \text { girls). } \\
\text { Source: pers. comms. } \\
\text { with author contacts }\end{array}$ \\
\hline $\begin{array}{l}\text { UNFPA/ } \\
\text { UNICEF (2013) }\end{array}$ & $\begin{array}{l}\text { Multi-ethnic. } \\
\text { Study of } 12 \\
\text { districts in } 5\end{array}$ & $\begin{array}{l}\text { Instruction for } \\
\text { girls, some in } \\
\text { seclusion; public }\end{array}$ & $\begin{array}{l}\text { Community } \\
\text { sensitization/education \& } \\
\text { dialogues; media }\end{array}$ & $\begin{array}{l}\text { Mixed methods 'emphasising } \\
\text { participatory approaches' inc. key } \\
\text { informant i/vs, group }\end{array}$ & $\begin{array}{l}\text { National prevalence figures } \\
\text { of } 27 \% \text { cited (KDHS } \\
2008 / 09) \text {. No specific }\end{array}$ & $\begin{array}{l}\text { 'Too early' to assess } \\
\text { long-term effects of } \\
\text { 'achievements' such }\end{array}$ \\
\hline
\end{tabular}


LIAS WORKING PAPER 1

\begin{tabular}{|c|c|c|c|c|c|c|}
\hline & $\begin{array}{l}\text { provinces where } \\
\text { UNFPA/UNICE } \\
\text { F Joint } \\
\text { Programme } \\
\text { against FGM/C } \\
\text { began 2008/09 }\end{array}$ & $\begin{array}{l}\text { declaration. Not } \\
\text { witnessed }\end{array}$ & $\begin{array}{l}\text { engagement; some follow-up } \\
\text { of girls after ARP }\end{array}$ & $\begin{array}{l}\text { discussions (inc. with girls who } \\
\text { had attended ARP), observations, } \\
\text { document review. } 292 \text { individuals } \\
\text { consulted. No surveys }\end{array}$ & $\begin{array}{l}\text { prevalence rates for the } \\
\text { intervention sites }\end{array}$ & $\begin{array}{l}\text { as ARP. Claims Joint } \\
\text { Programme helped } \\
\text { bring about national } \\
\text { legislation }\end{array}$ \\
\hline $\begin{array}{l}\text { Waritay \& } \\
\text { Wilson (2013) }\end{array}$ & $\begin{array}{l}\text { Tanzania: Mara, } \\
\text { Dodoma, Singida } \\
\text { Districts }\end{array}$ & $\begin{array}{l}\text { Not clearly } \\
\text { stated. ARP } \\
\text { seclusion and } \\
\text { training briefly } \\
\text { described for one } \\
\text { community }\end{array}$ & $\begin{array}{l}\text { Advocacy campaigns; } \\
\text { community education \& } \\
\text { sensitization, safe havens }\end{array}$ & $\begin{array}{l}22 \text { communities targeted ( } 8 \text { in } \\
\text { Mara \& Dodoma, } 6 \text { in Singida). } \\
\text { In each community data was } \\
\text { collected from a convenience } \\
\text { sample of members/staff of the } \\
\text { local church. Details unclear }\end{array}$ & $\begin{array}{l}\text { Self-reported (details unclear, } \\
\text { reference is made to } \\
\text { secondary data and } \\
\text { participant testimony) }\end{array}$ & \\
\hline $\begin{array}{l}\text { WHO (1999) } \\
\text { (by PATH) }\end{array}$ & $\begin{array}{l}\text { Survey of } 88 \\
\text { agencies with anti- } \\
\text { FGM/C } \\
\text { programmes } \\
\text { (Africa \& Middle } \\
\text { East) \& closer } \\
\text { analysis of } 4 \\
\text { African countries. } \\
\text { ARP only } \\
\text { mentioned for } \\
\text { Kenya \& Uganda } \\
\text { (Sabiny people) }\end{array}$ & $\begin{array}{l}\text { Kenya: } \\
\text { instruction for } \\
\text { girls in seclusion; } \\
\text { public ceremony. } \\
\text { Not clear if } \\
\text { witnessed or } \\
\text { authors only } \\
\text { citing MYWO } \\
\text { reports. Uganda: } \\
\text { 'symbolic } \\
\text { alternative' inc. } \\
\text { 'feasting and } \\
\text { giving of clothes } \\
\text { and jewellery' }\end{array}$ & $\begin{array}{l}\text { Kenya: community } \\
\text { sensitization/mobilization; } \\
\text { training of peer educators \& } \\
\text { ex-circumcisers; Family Life } \\
\text { Education. Uganda: } \\
\text { community seminars \& } \\
\text { workshops; youth trained as } \\
\text { peer educators; creation of a } \\
\text { regular 'cultural day' in the } \\
\text { community which celebrates } \\
\text { positive aspects of culture }\end{array}$ & $\begin{array}{l}\text { Lit review; questionnaires sent to } \\
\text { national \& international } \\
\text { organizations; field assessments } \\
\text { in } 4 \text { countries (not including } \\
\text { Kenya or Uganda). No baseline } \\
\text { or endline surveys. Mention of } \\
\text { ARP (mostly referred to as an } \\
\text { alternative coming of age } \\
\text { programme) in Kenya \& Uganda } \\
\text { cites reports by NGOs MYWO } \\
\text { \& REACH. No evaluation yet (in } \\
\text { time for study) by MYWO for } \\
\text { Kenya }\end{array}$ & $\begin{array}{l}\text { Country prevalence given for } \\
\text { those counties visited, but } \\
\text { not for Kenya \& Uganda, or } \\
\text { site-specific prevalence in } \\
\text { these } 2 \text { countries }\end{array}$ & $\begin{array}{l}\text { ARP is 'an effective } \\
\text { strategy in } \\
\text { communities where } \\
\text { girls are initiated } \\
\text { during the adolescent } \\
\text { years (12-19)'. No } \\
\text { hard evidence given. } \\
\text { Assumes ARP } \\
\text { graduates have been } \\
\text { 'saved' from FGM/C } \\
\text { (p.109) } \\
\text { Ugandan NGO } \\
\text { REACH reports } \\
\text { many community } \\
\text { members still support } \\
\text { FGM/C after } \\
\text { intervention }\end{array}$ \\
\hline
\end{tabular}

\section{Observations}

The main conclusion of our review of existing studies which have evaluated ARP interventions is that no study has yet concretely demonstrated the

positive impact of ARP interventions on the practice of FGM/C. The methodological limitations of existing studies mean that we simply cannot assess (a) whether the interventions evaluated actually generated changes in the practice of FGM/C (versus whether such changes would have occurred anyway); and 
(b) whether any changes that did occur can be attributed to the inclusion of ARP components in the interventions (as opposed to the generic community sensitization and educational activities which also occur in interventions without specific ARP components).

Most studies lacked any baseline measurement of the practice of FGM/C before the intervention; no study selected an adequate comparison group prior to the intervention taking place; and no study has apparently carried out long-term follow-up of ARP participants. For these reasons, in most studies, the reported change that occurred over the course of the intervention and afterwards could not be accurately assessed. In those few studies which included baseline surveys, there was no adequate comparison group, making it impossible to assess whether change would have occurred anyway, without the presence of an NGO. This is especially problematic because the communities targeted by NGOs were not targeted at random, and may represent those communities in which change was starting to occur anyway. Even assuming that changes were measured and attributed to the interventions, a further difficulty remains in disaggregating the impact of ARP from other generic intervention activities (notably community sensitization and awareness-raising) that usually take place alongside ARP. This is not a trivial problem since, as Chege et al. (2001) point out, NGOs must decide whether to dedicate resources to organising such activities, and how to allocate the available funds:

"In cultures that are clearly resistant to changing this behaviour [FGM/C] (e.g. the Abagusii and Maasai), should resources be allocated primarily to sensitisation, or to organising Alternative Rites, or to a combination?" (p.46)

A study with baseline and endline measurements comparing otherwise similar (but independent ${ }^{10}$ families or communities involved in generic and ARPthemed interventions (i.e. differing only in the inclusion of specific ARP elements such as instruction for girls and a public graduation ceremony), over an equivalent time period, may be needed to assess the impact of ARP components.

In addition to the methodological limitations of existing evaluation studies, we identified a number of conceptual difficulties in assessing the impact of $\mathrm{ARP}$ in anti-FGM/C interventions:

- Most authors do not appear to have directly observed ARP, including the instruction component, but relied on descriptions provided by other organizations at other study sites, sometimes of ARP interventions that took place decades earlier (e.g. the repeated reference to MYWO ARPs in Meru in the late 1990s), making it unclear exactly what activities had been evaluated at the study site/s

- Some authors refer to participation in ARP activities as if it were evidence of the abandonment of FGM/C and therefore the success of the intervention. But without long-term follow-up, we cannot know whether such activities promote long-term abandonment

- Very few studies discuss the traditional initiation rituals which ARP aims to replicate, but without FGM/C. Without deeper understanding of these rituals and their socio-psychological-cultural significance, it is hard to gauge what exactly ARP is attempting to replace, and whether the 'right' components are included (i.e. those likely to be culturally acceptable, because they mimic past custom, and may lead to the desired outcomes).

\footnotetext{
$10 \mathrm{By}$ independent we mean that they are not connected in a way which would allow the effects of one intervention to 'contaminate' the other. For instance, living in a community where ARP takes place might make it easier for a girl to go uncut even if she herself did not participate in the programme, simply because normative social pressure within the community to undergo FGM/C had been eased by the intervention.
} 
The second point touches on a wider issue discussed in Chege et al. (2001). These authors noted that families and girls are often targeted to participate in alternative rituals because they have already decided to renounce FGM/C, which makes it unclear whether ARP is supposed to persuade families to abandon FGM/C, or merely gather together families who already hold this view. Chege et al. suggest that ARP may provide social support to allow families who want to abandon FGM/C to actually do so, or it may simply provide an opportunity for families who have abandoned FGM/C to declare this publicly. If the former, then the measurement of the long-term impact of ARP on the FGM/C status of graduates should be a key measure of the success of such programmes - yet this is precisely what existing studies have been unable to assess. If the latter, then it becomes somewhat unclear what role ARP is meant to play in encouraging the abandonment of FGM/C. Furthermore, several studies, such as Dòcker (2011), note the importance of including outof-school children in anti-FGM/C interventions and data gathering; they currently appear to be under-represented, which further undermines the reliability of the existing data and raises questions about the selection of youth participants in ARP.

Our review can be considered complementary to a recent 'rapid evidence assessment' of interventions relating to FGM/C published by the Population Council (Esho et al., 2017). That review aimed to assess the quality of published evaluation studies on interventions relating to FGM/C (between 2000 and 2016), and the key findings of a subset of these which were rated as 'high' in quality (of which only three discussed ARP). The main differences between their review and ours concern which studies have been reviewed in detail, and how the evidence generated by those studies has been assessed. Esho et al. used guidance from the UK Department for International Development (DFID) to assess the quality of 70 evaluation studies relating to FGM/C interventions. Their assessment was based on a wide and quite general range of pre-specified criteria including 'conceptual framing', 'transparency' and 'reliability', whereas our review focuses on a narrower set of issues which we see as critical to addressing a key question: to what extent have published evaluations permitted robust inferences about the impact of ARP interventions on the practice of FGM/C? Reporting of ARP, study design and measurement of FGM/C practice in existing studies have been evaluated with this question in mind.

Of the 70 studies which met their inclusion criteria, Esho et al. (2017) reviewed in detail seven studies with primary data which they rated as being of high quality, covering a range of approaches including ARP. We have reviewed all studies identified as relevant to evaluating ARP and did not use quality criteria to focus on particular studies. Our primary aim has been to evaluate the methodology of these studies for the purpose of identifying what might usefully be evaluated in future research, rather than to synthesise their findings or to derive specific programme recommendations (as Esho et al. do to some extent). Unlike Esho et al., we have focused in particular on issues surrounding the evaluations of ARP interventions as a component of interventions that also contain non-ARP specific components. Despite these differences, the conclusions we have reached tally with those of Esho et al. in many ways. Esho et al. expressed concerns about the lack of baseline surveys in intervention studies and the lack of long-term follow-up of individuals and communities targeted by interventions to assess change, both of which are borne out by our analysis. Also, Esho et al. echoed the key conclusion of our review: that the design of studies thus far has not allowed for any firm conclusions to be made about the extent of the impact of intervention efforts over time. 